\title{
Local food consumption during the covid-19 pandemic
}

\author{
Zohra Ghali-Zinoubi ${ }^{1,2}$ \\ ${ }^{1}$ College of Administrative and Financial Sciences, Saudi Electronic University, Riyadh, Saudi Arabia; ${ }^{2}$ Higher Institute of \\ Management of Tunis, University of Tunis, Le Bardo, Tunisia
}

*Corresponding author: Zohra Ghali-Zinoubi, College of Administrative and Financial Sciences, Saudi Electronic University, Riyadh, Saudi Arabia \& Higher Institute of Management of Tunis., University of Tunis., Le Bardo, Tunisia. Email: zohragh@yahoo.fr

Received: 30 May 2021; Accepted: 6 October 2021; Published: 5 November 2021

(c) 2021 Codon Publications

OPEN ACCESS (c) (i) (우요

PAPER

\section{Abstract}

The influence of intrinsic quality, health consciousness, environmental awareness, local support, and proximity of process on consumers' intention to consume local food during the COVID-19 pandemic was tested, with food availability as a moderator. Online survey results were analyzed using a two-step structural equation modelling (SEM). Health consciousness was the major reason for consuming local food. Intrinsic quality and proximity of process were also significant drivers. Local support and environmental awareness have little impact on the intention to purchase local food. This study contributes to knowledge regarding the main factors driving local food consumption during a health crisis, providing directions.

Keywords: consumer behavior; COVID-19 pandemic; local food; purchase intention; Tunisia

\section{Introduction}

The Coronavirus Disease of 2019 (COVID-19) pandemic has dramatically upset people's everyday lives, brought about a global recession that the world had not witnessed since the Second World War, and created a health crisis around the world (Smith and Wesselbaum, 2020). The food sector and its stakeholders are particularly in the spotlight (Ben Hassen et al., 2021a; Galanakis, 2020) because food is essential for human survival, and therefore it cannot be placed under lockdown. Indeed, the emergence of COVID-19 has significantly affected the global food systems at several levels, i.e., for producers, distributors, and consumers (Cranfield, 2020; Qi et al., 2020; Xie et al., 2020). Notably, both consumption patterns and consumers' behavior changed as the pandemic progressed (Celimli and Adanacioglu, 2021; Eger et al., 2021; Yuen et al., 2020). In this context, what should be eaten has become one of the main concerns for customers who seek to improve their immunity and increase their food security. In April 2020, worldwide Google searches for "food delivery" and "local food" reached an all-time high (Shveda, 2020). Thus, the crisis forced people to reexamine the sources of their groceries and the mode through which they procured food.

In a globalized era, the distribution of food from the producer to geographically dispersed consumers relies on a large and complex supply chain. The coronavirus crisis has disrupted this supply chain and caused gaps in food delivery. Moreover, the lockdowns instituted in response to the COVID-19 pandemic have led to shortages of labor, interruptions of logistics, and inconsistency in the demand for and supply of food (Pantano et al., 2020; Rizou et al., 2020). This has resulted in empty supermarket shelves, food wastage, and hindered food procurement due to interruptions in exports and imports (Aday and Aday, 2020). Local food systems can alleviate this growing threat of the global food system crisis (Memery et al., 2015; Peterson, 2013; Pressman et al., 2020). The existing literature names several reasons for the increased demand for local food providers during the COVID19 
pandemic. First, during a health crisis, the most crucial issue for any consumer is to consume healthy, nutritious, and safe food, such as local food (Arsil et al., 2018; Skallerud and Wien, 2019). Second, during the pandemic, consumers have become more interested in what they consume and from where they source them (Severo et al., 2020; Sheth, 2020). The intrinsic quality of food matters more than ever (Ben Hassen et al., 2020). Local food is consumed quickly (Aprile et al., 2016; Loiseau et al., 2020). This ensures that it is fresher and more nutritious, with stronger immunity-boosting properties (Ozturk and Akoglu, 2020). Third, the distribution chain of local food is transparent, short, safe, and fair, because it is produced in the same geographic zone (Aprile et al., 2016; Roy et al., 2019; Toukabri and Ghali-Zinoubi, 2020). This reassures consumers and leads them to perceive the reduced risk of product contamination during its journey from the producer to the final consumer. Fourth, shorter distances between producers of local food and consumers are associated with reduced carbon impacts and waste production. Moreover, local production stimulates accountability among farmers, meaning that they will be more likely to engage in environmentally friendly practices (Mesić et al., 2020). Therefore, local foods are perceived as both sustainable and environmentally friendly products (Ozturk and Akoglu, 2020; Rousseau and Deschacht, 2020). Fifth, consuming locally available foods during times of crisis is a positive behavior that supports local producers and distributors, while consequently making consumers aware of their responsibility (Jribi et al., 2020; Mesić et al., 2020). However, the consumption of local food still depends on availability (Sowers et al., 2019). This is because local food increases customer trust, in addition to being accessible and easy to find (Kumar and Kashyap, 2018, Verma, 2020), thereby benefiting the retailer (Steinhart et al., 2013).

Tunisia is a Mediterranean country located in North Africa. Agriculture plays a vital role in its economy, and $10.1 \%$ of its Gross Domestic Product (GDP) in 2019 came from agricultural products. According to the Moderator Intelligence Report (MIR) of 2020, agricultural produce constitutes almost $6 \%$ of the total Tunisian exports. In 2019 , the vegetable production of this country exceeded 3.0 million metric tons, constituted by 545 metric tons of citrus, 288.7 metric tons of dates, and 130 metric tons of tomatoes. This country is the second-biggest exporter of organic foods (olive, date, vegetables, vines, orange, apple, etc.) in Africa with almost $80 \%$ of its production (MIR, 2020). However, Tunisia does not have food sovereignty, despite the important and varied local food production. It has had a trade deficit in agriculture production for several years (Almayed, 2019). For example, in 2020, Tunisia imported food for over 2.56 billion US dollars while its exports amounted only to 1.95 billion US dollars (Salah, 2021). Its leading agriculture imports are wheat (over 431 million US dollars), sugar (\$204 million), soybeans (\$162 million), vegetable oils (\$160 million), corn (\$145 million), and barley (\$134 million).

With the emergence of the COVID-19 pandemic and the breakdown, social distinction, and other restrictive measures taken in Tunisia and across the globe, the food supply faced several issues, while the food availability on the local market became a vital concern (Ben Hassen et al., 2021a; Kirkm and Kirkin, 2020; Pantano et al., 2020; Sheth, 2021). In this context of global breakdown and interruption of international transport, local food became the single viable alternative. Indeed, several studies conducted during the COVID-19 pandemic confirmed the growth of local food consumption amidst the pandemic (Ben Hassen et al., 2021b; Celimli and Adanacioglu, 2021; Duda-Chodak et al., 2020; Loiseau et al., 2020; Mesić et al., 2020). However, to the best of our knowledge, no studies have examined the factors driving this growth. Furthermore, from a marketing perspective, there are no studies focusing on the behavior of Tunisian consumers toward local food during the COVID-19 pandemic.

The current study was conducted in the aforementioned context to fill this gap. It examines motivations for local food consumption during the COVID-19 pandemic. The main objective of this paper was to examine the main motivations for local food consumption during the COVID-19 pandemic and the moderating role of food availability. This paper begins with a literature review, from which five hypotheses are derived. Next, the research methodology was developed. The discussion of the results and their implications are presented in the last section, which also includes the study's limitations and directions for future research.

\section{Literature Review}

\section{What is local food?}

The concept of "local food" has been the focus of several studies in the literature (Bazzani and Canavari, 2017; Bentsen and Pedersen, 2020; Meyerding et al., 2019; Picha et al., 2017). However, there is still no agreedupon definition of this concept (Memery et al., 2015; Skallerud and Wien, 2019). For instance, several studies have used an objective approach, defining local food in relation to the geographic distance that the food travels from the producer to the final customer. In other words, the term "local food" has been used to describe food systems or short supply chains wherein the food is produced in areas close to where the consumers live (Meyerding et al., 2019; Skallerud and Wien, 2019). However, this approach has been criticized because 
consumers may struggle to accurately assess the distance between producers and markets (the places of purchase), especially at higher levels of congruence. A perceptual approach has been developed as an alternative. It considers food as "local" based on the consumer perception, in other words it is local if the consumer subjectively believes it to be so. This approach is more versatile but has issues regarding reliability, especially when neighbors living on the same street estimate the same product differently. In this context, Bazzani and Canavari (2017, p. 514) suggested that the meaning of "local" should be expressed in terms of connection to a geographical area rather than in terms of food miles. Considering the advantages and disadvantages of both approaches, we will use the definition developed by the Industry of Global Distribution (IGD) (2005, p. 3), where "local food must be grown or produced within 30 miles of where the buyer lives."

\section{Motivation for local food consumption}

\section{Intrinsic quality}

The existent literature in marketing shows that intrinsic quality is an ambiguous and multidimensional concept. (Fandos and Flavian, 2006). It is among the most important criteria that consumers use to evaluate food products (Memery et al., 2015). The literature distinguishes between extrinsic and intrinsic quality. Intrinsic attributes consist of an objective quality assessment, are intangible, specific to every product, and cannot be altered without modifying the nature of the product (Fandos and Flavian, 2006). Several studies have found that consumers perceive local food as having superior intrinsic quality in terms of freshness, taste, naturalness, nutrition, health, and safety (Mesić et al., 2020; Meyerding et al., 2019; Roy et al., 2019). However, local food only presents these attributes if purchased from local producers, especially in their production season (Ozturk and Akoglu, 2020).

During the COVID-19 pandemic, strengthening immunity has become a major concern for consumers. Local foods meet these objectives for consumers because they consider them free from preservatives and chemicals, perceiving them as natural and wholesome. Such attributes are believed to provide health benefits (Memery et al., 2015). Therefore, intrinsic quality is important motivation for consumers to purchase local food during the pandemic (Mesić et al., 2020; Shveda, 2020). Given the above information, the first hypothesis of the study is as follows:

H1. During the COVID-19 pandemic, intrinsic quality positively influences consumers' intention to purchase local food.

\section{Health consciousness}

Health consciousness is the degree to which issues related to personal health are of concern to an individual $(\mathrm{Pu}$ et al., 2020). It also refers to the degree to which health-related actions are integrated into a person's everyday activities (Janetius and Krithik, 2020). Customers with high health consciousness are more likely to engage in healthy habits and take proactive measures to protect their health (Mesić et al., 2020; Pu et al., 2020). In addition, people have improved their health consciousness during the pandemic.

Local food is characterized by having a short distribution chain, freshness, and nutritional value, and by being harvested at the optimal stage (Roy et al., 2019). The consumption of local food during the coronavirus pandemic has grown because it is considered safer and healthier (Xie et al., 2020). Based on the arguments above, we hypothesize that:

H2. During the COVID-19 pandemic, health consciousness positively influences consumers' intention to purchase local food.

\section{Proximity to the production process}

Proximity to production refers to sharing knowledge of the internal functioning of trade (quality, origin, the production process, and the distribution chain) with customers (Bergadaà and Del Bucchia, 2009). In other words, proximity to the production is based on formal and informal exchanges of relevant and timely information to meet wishes and expectations of the actors involved in a transaction (Anderson and Narus, 1990). This proximity dimension shows customers the transparency of the manufacturing process and the useful, sanitary, and nutritious qualities of the product (Merle and Piotrowski, 2012). In geographically dispersed food systems, production and distribution chains are complex, large, and include several intermediaries (Loiseau et al., 2020; Roy et al., 2019; Todorovic et al., 2018). This means that the processes of production and distribution are not transparent to customers. Thus, easy access to the source of production leads to greater food security (Mazieres and Gauthier, 2015; Toukabri and Ghali-Zinoubi, 2020). Consequently, proximity to the production, which focuses on the relationship between the producer and consumer, becomes important to reassure customers, especially as safety and nutritious attributes of products are regarded (Loiseau et al., 2020; Skallerud and Wien, 2019). Local food chains have been found to meet these requirements (Todorovic et al., 2018).

During COVID-19, customers have become more concerned with health and the environment. Short and transparent production, distribution processes, and smaller supply chain have become essential criteria to 
reassure customers, minimize contamination risks, and increase food security (Hobbs, 2020; Mesić et al., 2020). Therefore, local food has fostered increasing interest among customers, and its consumption has grown prominently (Shveda, 2020). Thus, we hypothesize that:

H3. During the COVID-19 pandemic, proximity to the production process positively influences consumers' intention to purchase local food.

\section{Local support}

Consumption of local food has empathic, social, and local loyalty motivations (Skallerud and Wien, 2019). In fact, individuals consume local food to help local producers compete with national producers and imports (Mesić et al., 2020; Meyerding et al., 2019). It is a moral obligation (Peterson, 2013) and behavior in favor of the local community and retailers (Memery et al., 2015). An increase in local food consumption revitalizes the economy and plays a role in reducing the environmental damage that occurs while shipping food (e.g., carbon emissions) (Ozturk and Akoglu, 2020).

During the coronavirus pandemic, local restaurants and stores were temporary or extendedly closed. However, the "shop local" movement also increased during such times. Several studies have stated that consumers are more aware of the impact of the COVID-19 crisis on local suppliers, retailers, and the wider community (Severo et al., 2020). To support them and reduce the impact of the crisis on their activities, consumers are more motivated to purchase local food. This has been translated into favorable purchasing intention (Mesić et al., 2020). Based on this argument, we hypothesize that:

H4. During the COVID-19 pandemic, local support positively influences consumers' intention to purchase local food.

\section{Environmental awareness}

According to the World Health Organization (2020) report, the COVID-19 pandemic has highlighted that maintaining sanitation and hygienic conditions, providing safe water, and reducing air pollution are all crucial measures for protecting human health during any infectious disease outbreak. Rousseau and Deschacht (2020) analyzed the online search behavior of 20 European countries and found that public awareness of nature and the environment increased during the COVID-19 pandemic. This is because protecting the environment is an important factor in reducing the risk of infection (Severo et al., 2020). Consuming local food is a way to reduce environmental pollution and improve food safety, as it reduces the risk of contamination associated with a long supply chain, in addition to being more sustainable (Ozturk and Akoglu, 2020). Overall, a short distribution chain is associated with fewer negative environmental impacts (e.g., carbon emissions and other pollution forms), once there is less packaging and no need for shipping facilities, packing facilities, or refrigeration. Similarly, Jribi et al. (2020) identified a positive impact of COVID-19 on Tunisian consumer awareness in terms of attitudes and behaviors toward food waste. Therefore, we posit the following:

H5. During the COVID-19 pandemic, environmental awareness positively influences consumers' intention to purchase local food.

\section{Moderating role of food availability}

Food availability is a proxy of the service level provided to end customers (Lovel et al., 2005; Verma, 2020). Consumers have a positive perception of local food if it is accessible and available (Steinhart et al., 2013). The higher the availability of local food in the market, the higher is the familiarity of the consumer with its characteristics and, consequently, the perception of its values (Toukabri and Ghali-Zinoubi, 2020). Therefore, product availability increases the intention to purchase it. During the COVID-19 pandemic period, which was characterized by a general lockdown and restrictions on international transport, the demand for local food grew prominently (Duda-Chodak et al., 2020; Loiseau et al., 2020; Mesić et al., 2020). Food availability becomes crucial for local retailers to satisfy the increasing demand of their customers. This is because local food became the single viable alternative available for customers in several countries during the COVID-19 pandemic. Consumers consume local food to protect their health, environment, and the local community (Memery et al., 2015). Consequently, the following hypotheses are proposed:

H6. During the COVID-19 pandemic, local food availability strengthens the relationship between the purchase intention of the consumer and its predictors.

H6.a. During the COVID-19 pandemic, local food availability strengthens the relationship between intrinsic quality and purchase intention.

H6b. During the COVID-19 pandemic, local food availability strengthens the relationship between health consciousness and purchase intention.

H6c. During the COVID-19 pandemic, local food availability strengthens the relationship between proximity to the production process and purchase intention. 


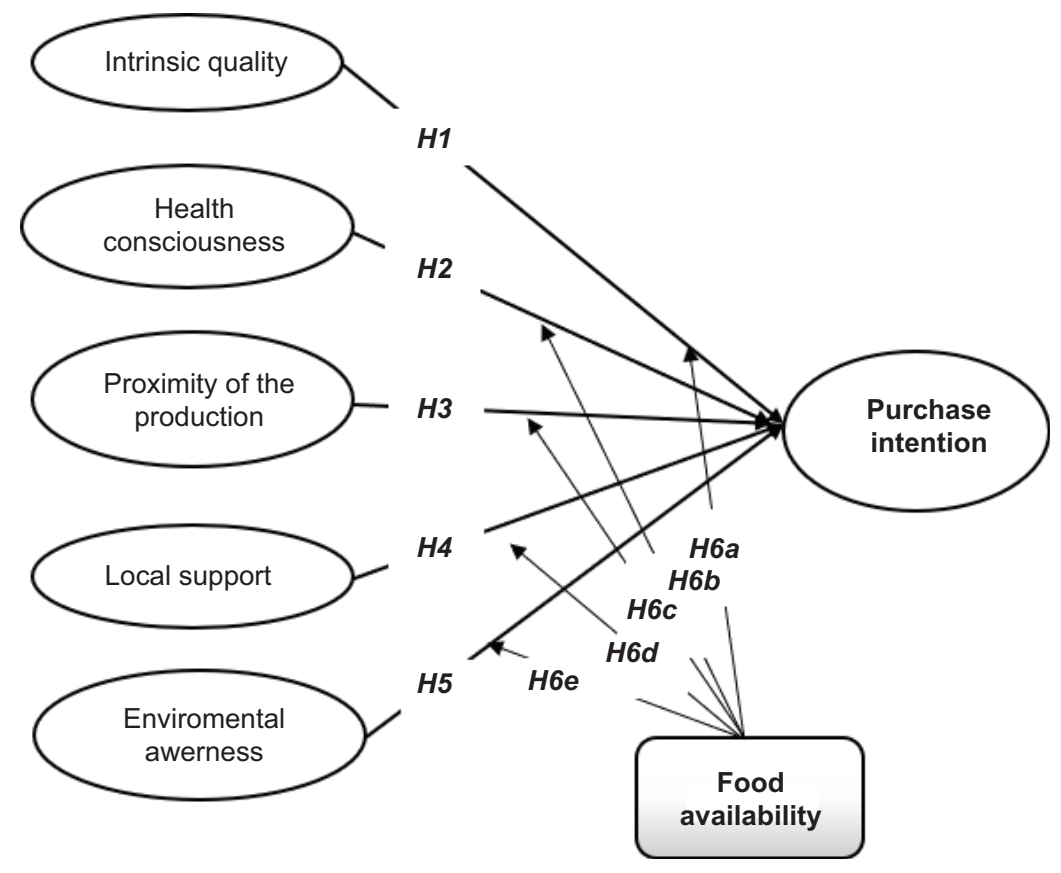

Figure 1. Proposed conceptual model.

H6d. During the COVID-19 pandemic, local food availability strengthens the relationship between local support and purchase intention.

H6e. During the COVID-19 pandemic, local food availability strengthens the relationship between the environmental awareness and purchase intention.

\section{Materials and Methods}

\section{Survey design}

The survey was designed using references from local food literature. The variable health consciousness was measured using Dutta-Bergman's (2004) five-item scale adapted to the coronavirus context ( $\mathrm{Pu}$ et al., 2020). Environmental awareness was measured using Severo et al's (2020) six-item scale. Local support was measured using Megicks et al's (2012) scale, which included three items. Proximity to the production was measured by adapting the Mazieres and Gautier (2015) scale. Intrinsic quality was measured using six items adapted from Megicks et al. (2012). Purchase intention was measured using the two-item scale of Lee et al. (2010), and food availability was measured using the four-item scale of Arsil et al. (2018). To adapt these measurement scales to the context of the coronavirus pandemic, the prefix "during the COVID-19 pandemic" was added to the different items as following $\mathrm{Pu}$ et al. (2020). All items were rated on a five-point Likert scale ranging from strongly agree to strongly disagree.

\section{Data collection}

The research context we chose was the country of Tunisia. The survey forms were made available online, using Google Forms. They were distributed mainly using email and social media networks (Facebook, LinkedIn, WhatsApp, and Instagram). The survey questionnaire was distributed using the convenience sampling approach. This speedy, easy, and low-cost technique does not allow the generalization of results (Yadav, 2016). However, it has provided pertinent and reliable findings in the context of food consumption studies (Ghali-Zinoubi, 2020, 2021).

A pre-study, including 23 surveys that were distributed to our family members and colleagues, was conducted to check the clarity and understandability of the survey. No revisions were made to the structure and content of the survey because respondents did not report any ambiguity or difficulty in understanding the questions.

The data were collected from May 03, 2020, to September 29,2020 . At the beginning of the survey, we provided examples of local food such as vegetables (potatoes, onions, spinach, parsley...), fruits (orange, apple, figs, peaches, apricots, etc.), eggs, meals, milk, and olive oil. They are the main local food produced in the different regions of Tunisia. In the end, 287 responses were returned out of 430 distributed questionnaires. However, we considered only 272 responses after eliminating incomplete or inappropriate (all answers were similar) responses. Table 1 summarizes the demographic profile of the sample. 
Table 1. Demographic description of the sample.

\begin{tabular}{|c|c|c|c|c|c|}
\hline Variables/criteria & $\mathbf{N}$ & $\%$ & Variables/criteria & $\mathbf{N}$ & $\%$ \\
\hline Gender & & & Education & & \\
\hline Female & 158 & 58.08 & Elementary and middle school & 23 & 8.45 \\
\hline Male & 114 & 41.92 & High school & 54 & 19.85 \\
\hline Age & & & Graduate & 122 & 44.85 \\
\hline $18-35$ & 68 & 25 & Postgraduate & 60 & 22.05 \\
\hline $36-59$ & 156 & 57.35 & $\mathrm{PhD}$ & 13 & 4.78 \\
\hline \multicolumn{6}{|l|}{ Older than 60} \\
\hline Main household & & & Household monthly income (TD)* & & \\
\hline Purchaser & 48 & 17.65 & Less than 1000 & 61 & 22.42 \\
\hline Myself & 113 & 41.54 & From 1001 to 1500 & 139 & 51.10 \\
\hline Other members & 102 & 37.5 & More than 1500 & 72 & 26.47 \\
\hline Both & 57 & 20.96 & & & \\
\hline
\end{tabular}

*TD: Tunisian Dinar. 1 TD = 0.36 US \$ in June 2021.

\section{Results and Discussion}

Data were analyzed using the SEM procedure. This method is considered appropriate as it examines simultaneous dependency among relationships (Severo et al., 2020, p. 6). To test the hypotheses of dependent relationships, both measurement and structural models will be assessed.

\section{Measurement model}

The reliability, and convergent and discriminant validities were tested using a Confirmatory Factor Analysis (CFA). The internal consistency of the survey items was measured using Cronbach's alpha $(\alpha)$. The values ranged from 0.789 to 0.887 , which exceeded the threshold of 0.7 established by Hair et al. (2013). The Composite Reliability (CR) scores ranged from 0.743 to 0.888 , exceeding the threshold established by Bagozzi et al. (1998). Therefore, the reliability of the scales of all constructs of the conceptual model was confirmed.

The convergent validity was tested through the factor loading and the Average Variance Extracted (AVE). The factor loading of all items was above 0.6 (ranging from 0.623 to 0.889), meeting Chin et al's (1997) criterion. In addition, the AVE value ranged from 0.611 to 0.785 , which was within the acceptable limit of 0.5 (Hair et al., 2013). Hence, convergent validity was confirmed for every construct. These results are summarized in Table 2.

The discriminant validity was also assessed by measuring the square root of AVE of each construct (Bagozzi and Yi, 1988). The results showed that they were higher than its correlation value (as shown in Table 3 ). This criterion was met for every construct. Thus, the discriminant validity is confirmed.

\section{Structural model}

\section{Goodness of fit indices}

The goodness of fit indices of the conceptual model was assessed using a structural model. The SEM results showed that the absolute, incremental, and parsimonious index values $\left(\mathrm{X}^{2}=206.429, \mathrm{X}^{2} / \mathrm{df}=2.788, \mathrm{FI}=0.912\right.$; TLI $=0.892 ;$ CFI $=0.911 ;$ IFI $=0.912 ;$ RMSEA $=0.04$ ) were well above the recommended thresholds (Bagozzi and Yi, 1988). Therefore, the conceptual model presents a good fit.

\section{Hypothesis testing and discussion}

\section{Test of direct impact}

To test the hypotheses, we examined $\beta$-values (the association between the independent and dependent constructs), t-values, and P-values. The path coefficients indicated that "intrinsic quality" and "health consciousness" had a positive significant influence on purchase intention $(\beta=0.428, \mathrm{t}$-value $=17.334 ; \mathrm{P}<0.01$ and $\beta=$ 0.449 , t-value $=22.267 ; \mathrm{P}<0.01$, respectively). Therefore, $\boldsymbol{H} \mathbf{1}$ and $\boldsymbol{H} \mathbf{2}$ were supported. These findings were in line with previous findings which showed that the health and the personal well-being of consumers are their main motivations for purchasing local food (Birch et al., 2020; Memery et al., 2015). This interest in maintaining health becomes more important in the era of COVID19 (Duda-Chodak et al., 2020; Janetius and Krithika, 2020). Furthermore, the "proximity to the production" also had a positive and significant influence on purchase intention $(\beta=0.388$, $\mathrm{t}$-value $=24.584 ; \mathrm{P}<0.05)$. 
Table 2. Measurement model: reliability and convergent validities.

\begin{tabular}{|c|c|c|c|}
\hline Measurement items & $\begin{array}{l}\text { Factor } \\
\text { loadings }\end{array}$ & t-values & $\begin{array}{l}\text { Cronbach's } \\
\boldsymbol{\alpha}\end{array}$ \\
\hline \multicolumn{4}{|l|}{ Intrinsic quality $(\mathrm{IQ})$ : $\mathrm{CR}=0.888 ; \mathrm{AVE}=0.733$} \\
\hline IQ1. During the COVID-19 pandemic, I buy local food because it is free from preservatives. & 0.834 & $24.734^{* *}$ & 0.827 \\
\hline IQ2. During the COVID-19 pandemic, I buy local food because it is free from chemicals. & 0.823 & $33.754^{* *}$ & 0.823 \\
\hline IQ3. During the COVID-19 pandemic, I buy local food because it is natural. & 0.788 & $34.842^{\star *}$ & 0.823 \\
\hline IQ4. During the COVID-19 pandemic, I buy local food because it is wholesome. & 0.887 & $31.783^{* *}$ & 0.851 \\
\hline IQ5. During the COVID-19 pandemic, I buy local food because it has a good appearance. & 0.754 & $26.647^{*}$ & 0.827 \\
\hline IQ6. During the COVID-19 pandemic, I buy local food produce because it lasts longer. & 0.742 & $24.752^{\star *}$ & 0.816 \\
\hline \multicolumn{4}{|l|}{ Health consciousness $(\mathrm{HC}): \mathrm{CR}=0.821 ; \mathrm{AVE}=0.785$} \\
\hline $\begin{array}{l}\text { HC1. During the COVID-19 pandemic, I feel that living life in the best possible health is very } \\
\text { important to me. }\end{array}$ & 0.823 & $36.754^{* *}$ & 0.887 \\
\hline $\begin{array}{l}\text { HC2. During the COVID-19 pandemic, eating right, exercising, and taking preventive } \\
\text { measures will keep me healthy for life. }\end{array}$ & 0.814 & $36.184^{* *}$ & 0.827 \\
\hline HC3. During the COVID-19 pandemic, my health depends on how well I take care of myself. & 0.889 & $13.762^{\star *}$ & 0.876 \\
\hline HC4. During the COVID-19 pandemic, I actively try to prevent disease and illness. & 0.837 & $24.818^{\star *}$ & 0.828 \\
\hline HC5. During the COVID19-19 pandemic, I do everything I can to stay healthy. & 0.847 & $19.528^{*}$ & 0.856 \\
\hline \multicolumn{4}{|l|}{ Environmental awareness (EA): CR = 0.789; AVE $=0.611$} \\
\hline $\begin{array}{l}\text { EA1. The COVID-19 Pandemic has made me increase the separation of organic and } \\
\text { recyclable waste. }\end{array}$ & 0.778 & $23.766^{*}$ & 0.803 \\
\hline $\begin{array}{l}\text { EA2. The COVID-19 pandemic has caused me to reduce water consumption further, as this } \\
\text { is a finite environmental resource. }\end{array}$ & 0.792 & $27.337^{*}$ & 0.789 \\
\hline $\begin{array}{l}\text { EA3. The COVID-19 Pandemic made me worry even more about the natural resources for } \\
\text { future generations. }\end{array}$ & 0.763 & $36.547^{\star *}$ & 0.823 \\
\hline EA4. The COVID-19 Pandemic made you realize the reduction in air pollution. & 0.811 & $17.831^{*}$ & 0.811 \\
\hline $\begin{array}{l}\text { EA5. The COVID-19 Pandemic made me realize, even more, the environmental impact } \\
\text { caused on the planet. }\end{array}$ & 0.801 & $22.781^{\star *}$ & 0.793 \\
\hline EA6. The COVID-19 Pandemic has increased my environmental awareness. & 0.788 & $24.972^{*}$ & 0.801 \\
\hline \multicolumn{4}{|l|}{ Local support (LS): CR = 0.816; AVE $=0.743$} \\
\hline LS1. During the COVID-19 pandemic, I buy local food to support local producers. & 0.623 & $28.627^{\star *}$ & 0.844 \\
\hline LS2. During the COVID-19 pandemic, I buy local food to support local retailers. & 0.688 & $26.738^{\star *}$ & 0.822 \\
\hline LS3. During the COVID-19 pandemic, I buy local food to support the local community. & 0.724 & $24.343^{*}$ & 0.773 \\
\hline \multicolumn{4}{|l|}{ Proximity of process $(P P): C R=0.833 ; A V E=0.713$} \\
\hline $\begin{array}{l}\text { PP1. During the COVID19 pandemic, I am interested to know very well the rules of } \\
\text { production and distribution of the local foods. }\end{array}$ & 0.854 & $28.972^{* *}$ & 0.851 \\
\hline $\begin{array}{l}\text { PP2. During the COVID-19 pandemic, I am interested in being very familiar with the } \\
\text { production methods used by the producers who produce this local food. }\end{array}$ & 0.836 & $27.384^{* \star}$ & 0.802 \\
\hline $\begin{array}{l}\text { PP3. During the COVID-19 pandemic, I am interested to know as to who the producers of } \\
\text { this local food are. }\end{array}$ & 9.812 & $31.827^{\star \star}$ & 0.826 \\
\hline \multicolumn{4}{|l|}{ Purchase intention $(\mathrm{PI}): \mathrm{CR}=0.743 ; \mathrm{AVE}=0.776$} \\
\hline PI1. During the COVID-19 pandemic, I am willing to buy local food while shopping. & 0.845 & $18.993^{* *}$ & 0.881 \\
\hline $\begin{array}{l}\text { PI2. During the COVID-19 pandemic, I will make an effort to buy local food in the near } \\
\text { future. }\end{array}$ & 0.844 & $21.366^{* *}$ & 0.823 \\
\hline \multicolumn{4}{|l|}{ Availability: $\mathrm{CR}=0.811 ; \mathrm{AVE}=0.783$} \\
\hline AV1. During the COVID-19 pandemic, local food is available. & 0.833 & $17.529^{* *}$ & 0.842 \\
\hline AV2. During the COVID-19 pandemic, local food is easier to find. & 0.833 & $12.333^{* *}$ & 0.827 \\
\hline AV3. During the COVID-19 pandemic, local food has cheaper price. & 0.853 & $21.023^{* *}$ & 0.852 \\
\hline AV.4. During the COVID-19 pandemic, local food provides an assurance of product origin. & 0.845 & $21.333^{* *}$ & 0.783 \\
\hline
\end{tabular}

Note: " $P<0.01 .{ }^{*} P<0.05$. 
Table 3. Discriminant validity test.

\begin{tabular}{|c|c|c|c|c|c|c|c|}
\hline Latent variables & IQ & $\mathrm{HC}$ & EA & LS & PP & PI & AV \\
\hline IQ & 0.856 & & & & & & \\
\hline $\mathrm{HC}$ & $0.534^{* *}$ & 0.886 & & & & & \\
\hline EA & $0.675^{\star *}$ & $0.373^{* *}$ & 0.781 & & & & \\
\hline LS & $0.531^{* *}$ & $0.462^{* *}$ & $0.422^{* *}$ & 0.861 & & & \\
\hline PP & $0.674^{*}$ & $0.561^{* *}$ & $0.372^{*}$ & $0.467^{* *}$ & 0.844 & & \\
\hline PI & $0.554^{* *}$ & $0.333^{* *}$ & $0.323^{*}$ & $0.556^{\star *}$ & $0.324^{*}$ & 0.880 & \\
\hline AV & $0.621^{* *}$ & $0.234^{* *}$ & $0.341^{* *}$ & 0.433 & 0.233 & $0.33^{* *}$ & 0.793 \\
\hline $\begin{array}{l}\text { MEAN } \\
\text { (S.D) }\end{array}$ & $\begin{array}{c}4.266 \\
(0.4316)\end{array}$ & $\begin{array}{c}4.333 \\
(4.363)\end{array}$ & $\begin{array}{c}4.233 \\
(0.466)\end{array}$ & $\begin{array}{c}4.666 \\
(0.522)\end{array}$ & $\begin{array}{c}4.666 \\
(0.492)\end{array}$ & $\begin{array}{l}4.301 \\
(0.449)\end{array}$ & $\begin{array}{l}4.001 \\
(0.692)\end{array}$ \\
\hline
\end{tabular}

Notes: " $\mathrm{*}<0.01$; $\mathrm{*}<<0.05$. S.D: Standard Deviation. The square roots of AVEs are the numbers written in bold on the diagonal. Numbers

below the diagonal represent constructs' correlations.

Hence, $\boldsymbol{H} \mathbf{3}$ was supported. This finding was in line with Toukabri and Ghali-Zinoubi (2020). The common point among the three predictors was that they expressed selfinterest ("what is good for me") by focusing on concerns over health, safety, and well-being, which translated into self-centered motivations (Birch et al., 2018). During the COVID-19 pandemic, this interest in health and safety gained additional attention ( $\mathrm{Pu}$ et al., 2020). The strong association between self-centered motivations and behavioral intentions is justified by the fact that local food meets health and safety requirements (Birch et al., 2018; Mesić et al., 2020; Meyerding et al., 2019).

The influence of "local support" on purchase intention was positive and significant $(\beta=0.111$, $\mathrm{t}$-value $=10.233$; $\mathrm{P}<0.05)$. Therefore, $\boldsymbol{H} 4$ was supported. This finding was in line with Memery et al. (2015) and Arsil et al. (2018). The construct "environmental awareness" had a positive influence on purchase intention, but the relation was weak $(\beta=0.043$, $\mathrm{t}$-value $=1.633 ; \mathrm{P}>0.05)$. Therefore, $\boldsymbol{H} 5$ was not supported. These two variables expressed a "do good" for the environment and wider community, which translated into altruistic motivations (what is good for "us"). The findings of this study showed a weak impact of the

Table 4. Hypothesis testing.

\begin{tabular}{lcccc} 
& Path & $\boldsymbol{\beta}$-values & t-statistics & Relationship \\
\hline H1 & IQ $\rightarrow$ PI & 0.428 & $17.334^{* *}$ & Supported \\
H2 & HC $\rightarrow$ PI & 0.449 & $22.267^{* *}$ & Supported \\
H3 & $\mathrm{PP} \rightarrow \mathrm{PI}$ & 0.388 & $24.584^{*}$ & Supported \\
H4 & LS $\rightarrow \mathrm{PI}$ & 0.111 & $10.233^{*}$ & Supported \\
H5 & EA $\rightarrow$ PI & 0.043 & 1.633 & Not supported
\end{tabular}

Note: "P $<0.01$. .P $<0.05, \mathrm{IQ}$ : Intrinsic quality; HC: Health consciousness, PP: Proximity of process, LS: Local support, EA: Environmental awareness, PI: Purchase intention. altruistic motivations compared with self-centered ones, although local support was a significant driver of intention of purchasing local food. Likewise, Rousseau and Deschacht (2020) analyzed online search behavior in the European Union and found that the COVID-19 crisis did not affect public awareness of environmental issues. Birch et al. (2018) also reported a stronger impact of self-centeredness than of altruism in the context of local food consumption. However, Severo et al. (2020) conducted a study in Portugal and Brazil and found that the pandemic was instrumental in people's behavioral change, increasing environmental awareness and sense of social responsibility. These results are summarized in Table 4 .

\section{Test of the moderating role of local food availability}

The moderating role of food availability (Table 5) was significant for the relationships between intrinsic quality and purchase intention, health consciousness and purchase intention, and proximity to the production and purchase intention. However, it was weak in the relationship between local support and purchase intention, and environmental awareness and purchase intention. These results show that regardless of food availability, the

Table 5. Hypothesis testing.

\begin{tabular}{llccl} 
& Path & $\boldsymbol{\beta}$-values & t-statistics & Relationship \\
\hline H6a & IQ ${ }^{*} \mathrm{AV} \rightarrow \mathrm{PI}$ & 0.223 & $6.333^{*}$ & Supported \\
$\mathrm{H} 6 \mathrm{~b}$ & $\mathrm{HC}{ }^{*} \mathrm{AV} \rightarrow \mathrm{PI}$ & 0.154 & $3.667^{* *}$ & Supported \\
$\mathrm{H} 6 \mathrm{c}$ & $\mathrm{PP}{ }^{*} \mathrm{AV} \rightarrow \mathrm{PI}$ & 0.111 & $11.628^{*}$ & Supported \\
$\mathrm{H} 6 \mathrm{~d}$ & $\mathrm{LS}{ }^{*} \mathrm{AV} \rightarrow \mathrm{PI}$ & 0.033 & 1.333 & Not supported \\
$\mathrm{H} 6 \mathrm{e}$ & $\mathrm{EA}{ }^{*} \mathrm{AV} \rightarrow \mathrm{PI}$ & 0.004 & 1.066 & Not supported \\
\hline
\end{tabular}

Note: ${ }^{* *} \mathrm{P}<0.01 .{ }^{*} \mathrm{P}<0.05$; IQ: Intrinsic quality; HC: Health consciousness, PP: Proximity of process, LS: Local support, EA: Environmental awareness, PI: Purchase intention, AV: Availability. 
consumer was more self-centered than altruistic during the COVID-19 pandemic. In other words, the consumer intent to purchase local food is mainly due to its good quality and health benefits, irrespective of its availability. These results are in line with Toukabri and Ghali-Zinoubi (2020).

\section{Conclusion, Implications, and Limitations}

The findings indicate that, during the COVID-19 pandemic, health consciousness is the highest motive for consuming locally. Intrinsic quality and proximity to the production chain are also significant drivers of local food consumption. However, local support and environmental awareness have little impact on the intention to purchase local food. Food availability plays an important moderating role in three relationships (health consciousness/ purchase intention, intrinsic quality/purchase intention, and proximity to the production/purchase intention). Many people have become more concerned with what they eat and from where they purchase their food. These findings also have several theoretical and managerial implications.

\section{Theoretical implications}

This study enhanced the theoretical background of local and healthy food. First, several studies have argued that local food consumption is more important than ever, during the COVID-19 pandemic (Ben Hassen et al., 2021b; Cranfield, 2020; Duda-Chodak et al., 2020; Naja and Hamadeh, 2020; Rizou et al., 2020). Other studies have argued that this growth is because local food is safe, healthy, and accessible (Aprile et al., 2016; Arsil et al., 2018; Meyerding et al., 2019; Ozturk and Akoglu, 2020). However, this study tested more predictors of local food consumption, such as proximity to the production and local support. Then, it may be considered among the first to test these predictors in the context of the COVID-19 pandemic. Second, this paper examined the impact of both self-centered and altruistic motivators on the intention to purchase local food. The findings showed that self-centered motivations are important drivers for local food consumption while the effect of altruistic motivations is still too weak. The study was developed in the context of a developing country (Tunisia), where environmental consciousness is still in its early stage (Ghali-Zinoubi, 2021). These findings are in contrast to those of several other studies which were conducted in developed countries and argued that both motivators are important (Rousseau and Deschacht, 2020; Skallerud and Wien, 2019). Third, this study is among the few studies that examine the moderating role of food availability on consumers' purchase intention during the COVID-19 pandemic. The findings indicated that the pandemic strengthened the relationships between self-centered motivations and purchase intention. However, it was not significant for altruistic relationships. This means that during the COVID-19 pandemic, local food, if available, is mainly purchased for health protection, accessibility, and its high quality.

\section{Managerial implications}

The findings of this study showed that during the coronavirus pandemic, consumers purchased local food because of its superior intrinsic quality, health benefits, and accessibility. Practitioners would be wise to focus their marketing campaigns considering these features to boost the consumption of their products during, as well as after, the pandemic. Appropriate packaging, effective labeling strategies, and coherent branding promoting these benefits of local foods should be implemented to attract customers and increase their local food consumption. Moreover, advertising should highlight known features, such as superior intrinsic quality, supporting local food, and healthy ingredients. Marketers of local food should communicate slogans such as "proudly eating local food" or "tastier, healthier, more nutritious and safer food." Local retailers may also extend their support to local producers by providing details pertaining to the local source of produce and enhancing the transparency of their supply chain. Moreover, local food producers and the wider community can act as a unique platform to improve sales of existing food products and invent new products both during and after the current health crisis.

Governments should also play an active role to make local food more available by supporting local farmers with the required infrastructure, providing seeds and other financial aids. Furthermore, a suitable program should be added to local curricula to educate the next generation of consumers about the importance of local products. Local support has been found to have a significant impact on consumer intention to purchase local food. Several scholars have argued that COVID-19 has disrupted and changed consumer habits, lifestyles, and long-term behaviors (Naja and Hamadeh, 2020; Picha et al., 2017; Pressman et al., 2020; Qi et al., 2020). The pandemic brought the community closer together and highlighted the need to address social inequalities. Marketers should emphasize the importance of supporting local businesses and the wider community while building branding messages and communication strategies that focus on the attributes we presented. Such messages should inform and educate the public about the economic, environmental, and social benefits to be 
gained by purchasing local food. Because local food is considered a facet of local tradition, its consumption can be encouraged through traditional, cultural, and religious events. Environmental consciousness has been found to have a weak association with the intention to purchase local food. Marketers should build aggressive awareness campaigns to enhance the interest of ecofriendly consumers in local foods. These steps would increase local food consumption during and after the pandemic.

\section{Limitations and future research directions}

This paper fills the gap in the literature regarding the motivation for local food consumption during the COVID-19 pandemic, particularly in a developing market. However, some limitations should be underlined to guide future studies. First, data were collected through convenience sampling. This method is speedy, easy, and low cost; however, it hinders generalizability and replicability of results. Second, this study was developed in a single country. Cross-cultural studies would increase the inclusiveness of the research. Third, in this study, the motivations for purchasing local food were limited to five. However, several other motivations can be studied, such as short supply chains, local identities, ethical identities, past uses, and interest in traceability. Fourth, in this study, the focus was on the main drivers of local food purchase intention while the barriers were not studied. Future research should examine barriers that could inhibit consumers from purchasing local food, including high price, availability, and diversity.

Finally, the COVID-19 issue has taught us that individual action yields benefits that are multiplied when implemented on a global scale. We can master the crisis and flatten the curve of its progression if we work together. The influence of human behavior on personal and public well-being, including health protection, environmental preservation, and local support, has been highlighted by the COVID-19 pandemic. Humans must focus on being altruistic rather than self-centered to have a beneficial impact on those areas.

\section{Acknowledgments}

The author thanks all those who participated in the online survey for their valuable contributions to study data collection.

\section{Conflict of Interest}

There are no conflicts of interest. The author strictly followed all ethical guidelines.

\section{References}

Aday, S. and Aday, M.S., 2020. Impact of COVID-19 on food supply chain, Food Quality and Safety, 4: 167-180. https://doi. org/10.1093/fqsafe/fyaa024.

Almayed, A., 2019. Food security in Tunisia: a need to move back to sovereignty, perspectives 2/2019: ecological and social transformation in Africa: rethinking food systems for a $+2^{\circ} \mathrm{C}$ world. Available at: https://www.boell.de/en/2020/02/10/ ecological-and-social-transformation-africa.

Anderson, J.C. and Narus, J.A., 1990. A model of distributor firm and manufacturer firm working partnerships. Journal of Marketing 54: 42-58. https://doi.org/10.2307/1252172

Aprile, M.C., Caputo, V. and Nayga, R.M., Jr., 2016. Consumers' preferences and attitudes toward local food products. Journal of Food Products Marketing 22(1): 19-42. https://doi.org/10.1080/ 10454446.2014.94.9990

Arsil, P., Brindal, M. and Muyani, K., 2018. Determinants of consumers' preferences for local food: a comparison study from urban and rural areas in Indonesia. Journal of Business and Retail Management Research (JBRMR). 13(2): 184-195. https:// doi.org/10.24052/JBRMR/V13IS02/ART-16

Bagozzi, R. and Yi, Y., 1988. On the evaluation of structure equation models. Journal of the Academy of Marketing Science 16: 74-94. https://doi.org/10.1007/BF02723327

Bagozzi, R.P., Yi, Y. and Nassen, K.D., 1998. Representation of measurement error in marketing variables: review of approaches and extension to three-facet designs. Journal of Econometrics 89(1): 393-421. https://doi.org/10.1016/S0304-4076(98)00068-2

Bazzani, C. and Canavari, M., 2017. Is local a matter of food miles or food traditions? Italian Journal of Food Science 29(3): 505-517. https://doi.org/10.14674/IJFS-733

Ben Hassen, T., El Bilali, H. and Allahyari, M.S., 2020. Impact of COVID-19 on food behavior and consumption in Qatar. Sustainability 12: 6973. https://doi.org/10.3390/su12176973

Ben Hassen, T., El Bilali, H., Allahyari, M.S., Berjan, S. and Fotina, O., 2021a. Food purchase and eating behavior during the COVID-19 pandemic: a cross-sectional survey of Russian adults. Appetite 165(10): 105309. https://doi.org/10.1016/j.appet.2021.105309

Ben Hassen, T., El Bilali, H., Allahyari, M.S. and Charbel, L., $2021 \mathrm{~b}$. Food shopping, preparation and consumption practices in times of COVID-19: case of Lebanon. Journal of Agribusiness in Developing and Emerging Economies ahead-of-print(ahead-ofprint). https://doi.org/10.1108/JADEE-01-2021-0022

Bentsen, K. and Pedersen, P.E., 2020. Consumers in local food markets: from adoption to market co-creation? British Food Journal 123(3): 1083-1102. https://doi.org/10.1108/BFJ-03-20200173

Bergadaà, M. and Del Bucchia, C., 2009. La recherche de proximité par le client dans le secteur de la grande consommation alimentaire. Revue management \& avenir 121: 121-135. https://doi. org/10.3917/mav.021.0121

Birch, D., Memery, J. and. Kanakaratne, M.S., 2018. The mindful consumer: balancing egoistic and altruistic motivations to purchase local food. Journal of Retailing and Consumer Services 40: 221-228. https://doi.org/10.1016/j.jretconser.2017.10.013 
Celimli, S. and. Adanacioglu, H., 2021. Comparison of social media platforms in terms of marketing performances of food companies. Italian Journal of Food Science 33(2): 54-62. https://doi. org/10.15586/ijfs.v33i2.2031

Chin, W.W., Gopal, A. and Salisbury, W.D., 1997. Advancing the theory of adaptive structuration: the development of a scale to measure faithfulness of appropriation. Information Systems Research 8(4): 342-367. https://doi.org/10.1287/isre.8.4.342

Cranfield, J.A.L., 2020. Framing consumer food demand responses in a viral pandemic. Canadian Journal of Agricultural Economics, 68: 151-156. https://doi.org/10.1111/cjag.1224.

Duda-Chodak, A., Lukasiewicz, M., Ziec, G., Florkiewicz., A. and Filipiak-Florkiewicz, A., 2020. COVID-19 pandemic and food: present knowledge, risks, consumers fears and safety. Trends in Food Science \& Technology 105: 145-160. https://doi. org/10.1016/j.tifs.2020.08.020

Dutta-Bergman, M.J., 2004. Primary sources of health information: comparisons in the domain of health attitudes, health cognitions, and health behaviors. Health Communication 16(3): 273288. https://doi.org/10.1207/S15327027HC1603_1

Eger, L., kaKomárková, L., Egerováa, D. and Mičík, M., 2021. The effect of COVID-19 on consumer shopping behaviour: generational cohort perspective, Journal of Retailing and Consumer Services 61: 102542. https://doi.org/10.1016/j.jretconser. 2021.102542

Fandos, C. and Flavian, C., 2006. Intrinsic and extrinsic quality attributes loyalty and buying intention: an analysis for a PDO product. British Food Journal 108(8): 646-662. https://doi. org/10.1108/00070700610682337

Galanakis, C.M., 2020. The food systems in the era of the coronavirus (COVID-19) pandemic crisis. Foods. 9(4): 1-10. https://doi. org/10.3390/foods 9040523

Ghali-Zinoubi, Z., 2020. Effect of utilitarian and hedonic values on consumer willingness to buy and to pay for organic olive oil in Tunisia. British Food Journal 122(4): 1013-1026. https://doi. org/10.1108/BFJ-06-2019-0414

Ghali-Zinoubi, Z., 2021. Effects of organic food perceived values on attitude and behavior in developing country: role of price sensitivity. Pakistan Journal of Agricultural Sciences 58(3): 779-788. https://doi.org/10.1007/s13197-020-04618-9

Hair, J.F., Ringle, C.M. and Sarstedt, M., 2013. Partial least squares structural equation modelling: rigorous applications, better results and higher acceptance, Long Range Planning 46(1-2): 1-12. Available at: https://ssrn.com/abstract $=2233795$.

Hobbs, J.E., 2020. Food supply chains during the COVID-19 pandemic. Canadian Journal of Agricultural Economics 68: 171176. https://doi.org/10.1111/cjag.12237

IGD, 2005. The local and regional food opportunity. The Institute of Grocery Distribution, Watford, ND, pp. 1-8.

Janetius, S.T. and Krithika, S., 2020. Health consciousness and health knowledge among yoga enthusiasts during COVID-19 pandemic 2020: a qualitative analysis. International Journal of Health Sciences and Research 5(4). Available at: http://ijshr. com/IJSHR_Vol.5_Issue.4_Oct2020/IJSHR001.pdf.

Jribi, S., Ben Ismail, H., Doggui, D. and Debbabi, H., 2020. COVID19 virus outbreak lockdown: what impacts on household food wastage? Environment, Development and Sustainability 22: 3939-3955. https://doi.org/10.1007/s10668-020-00740-y

Kirkm, C.P. and Rifkin, R.S., 2020. I'll trade you diamonds for toilet paper: consumer reacting, coping and adapting behaviors in the COVID-19 pandemic. Journal of Business Research 117: 124131. https://doi.org/10.1016/j.jbusres.2020.05.028

Kumar, A. and Kashyap, A.K., 2018. Leveraging utilitarian perspective of online shopping to motivate online shoppers. International Journal of Retail \& Distribution Management 46(3): 247-263. https://doi.org/10.1108/IJRDM-08-2017-0161

Loiseau, E., Colin, M., Alaphilippe, A., Coste, G. and Roux, P., 2020. To what extent are short food supply chains (SFSCs) environmentally friendly? Application to French apple distribution using life cycle assessment. Journal of Cleaner Production 276: 124166. https://doi.org/10.1016/j.jclepro.2020.124166

Lovel, A., Saw, R. and Stimson, J., 2005. Product value-density: managing diversity through supply chain segmentation. International Journal of Logistics Management 16(1): 142-158. https://doi.org/10.1108/09574090510617394

Mazieres and Gauthier, 2015. Achat de produits locaux et proximité perçue en Grandes Surfaces Alimentaires. In: Acte of Etienne Thill annuel conférence, October, Paris, pp. 14-16.

Megicks, P., Memery, J. and Angel, R., 2012. Understanding local food shopping: unpacking the ethical dimension. Journal of Marketing Management 28(3-4): 264-289. https://doi.org/10.1 080/0267257X.2012.658838

Memery, J., Angell, R., Megicks, P. and Lindgreen, A., 2015. Unpicking motives to purchase locally-produced food: analysis of direct and moderation effects. European Journal of Marketing 49(7/8): 1207-1233. https://doi.org/10.1108/EJM-02-2014-0075

Merle, A. and Piotrowski, M., 2012. Consommer des produits alimentaires locaux - comment et pourquoi? Décision Marketing 67: 37-48. https://doi.org/10.7193/DM.067.37.48

Mesić, Z., Petljak, K., Borović, D. and Tomić, M., 2020. Segmentation of local food consumers based on altruistic motives and perceived purchasing barriers: a Croatian study. Economic Research- Ekonomska Istraživanja. 34(1): 221-242. https://doi.org/10.1080/1331677X.2020.1782243

Meyerding, S.G.H., Trajer, N. and Lehberger, M., 2019. What is local food? The case of consumer preferences for local food labeling of tomatoes in Germany. Journal of Cleaner Production 207: 30-43. https://doi.org/10.1038/s41430-020-0634-3

Moderator Intelligence, 2020. Tunisia fruit and vegetable market growth, trends, COVID-19 impact, and forecasts (20212026). Available at: https://www.mordorintelligence.com/ industry-reports/tunisian-fruit-vegetable-market.

Naja, F. and Hamadeh, R., 2020. Nutrition amid the COVID-19 pandemic: a multi-level framework for action. European Journal of Clinical Nutrition 74, 1117-1121 . https://doi.org/10.1038/ s41430-020-0634-3

Ozturk, S.B. and Akoglu, A., 2020. Assessment of local food use in the context of sustainable food: a research in food and beverage enterprises in Izmir, Turkey. International Journal of Gastronomy \& Food Science 20: 100194. https://doi.org/10.1016/j.ijgfs.2020.100194.

Pantano, E., Pizzi, G., Scarpi, D. and Dennis, C., 2020. Competing during a pandemic? Retailers' ups and downs during the 
COVID-19 outbreak. Journal of Business Research 116: 209213. https://doi.org/10.1016/j.jbusres.2020.05.036

Peterson, G.R., 2013. Is eating locally a moral obligation? Journal of Agricultural and Environmental Ethics 26: 421-437. https://doi. org/10.1007/s10806-012-9397-8

Pícha, K., Navrátil, J. and Švec, R., 2017. Preference to local food vs. preference to "national" and regional food. Journal of Food Products Marketing 24(2): 125-145. https://doi.org/10.1080/10 45444.6.2016.126654.9

Pressman, P., Naidu, A. and Clemens, R., 2020. COVID-19 and food safety. Nutrition Today 55(3): 125-128. https://doi.org/10.1097/ NT.0000000000000415

Pu, B., Zhang, L., Tang, Z. and Qiu, Y., 2020. The relationship between health consciousness and home-based exercise in China during the COVID-19 pandemic. International Journal of Environmental Research and Public Health 17: 5693. https://doi. org/10.3390/ijerph17165693

Qi, X., Yu, H. and Ploeger, A., 2020. Exploring influential factors including COVID-19 on green food purchase intentions and the intention-behaviour gap: a qualitative study among consumers in a Chinese context. International Journal Environmental Research and Public Health 17: 1-22. https://doi.org/10.3390/ ijerph17197106

Rizou, M., Galanakis, I.M., Aldawoud, T.M.S. and Galanakis, C.M., 2020. Safety of foods, food supply chain and environment within the COVID-19 pandemic, Trends in Food Science \& Technology. 102: 293-299. https://doi.org/10.1016/j.tifs.2020.06.008

Rousseau, S. and Deschacht, N., 2020. Public awareness of nature and the environment during the COVID-19 crisis. Environmental and Resource Economics Journal, 76: 11491159. https://doi.org/10.1007/s10640-020-00445-w

Roy, H., Hall, C.M. and Ballantine, P.W., 2019. Connecting local food to foodservice businesses: an exploratory qualitative study on wholesale distributors "perceived benefits and challenges." Journal of Foodservice Business Research 22(3): 261-285. https://doi.org/10.1080/15378020.2019.1600891

Salah, M., 2021. Value of imports and exports in the agriculture and food sector in Tunisia from 2018 to 2020. Statista. Available at: https://www.statista.com/statistics/1190806/ import-and-export-of-agriculture-and-food-in-tunisia/.

Severo, E.A., De Guimaraes, J.C. and Dellarmelin, M.L., 2020. Impact of the COVID-19 pandemic on environmental awareness, sustainable consumption and social responsibility: evidence from generations in Brazil and Portugal. Journal of
Cleaner Production 286: 124947 https://doi.org/10.1016/j. jclepro.2020.124.947

Sheth, J., 2020. Impact of covid-19 on consumer behavior: will the old habits return or die? Journal of Business Research 117: 280283. https://doi.org/10.1016/j.jbusres.2020.05.059

Shveda, K., 2020. How coronavirus is changing grocery shopping? BBC \& Corteva Agriscience. Available at: https://www.bbc.com/ future/bespoke/follow-the-food/how-covid-19-is-changingfood-shopping.html.

Skallerud, K. and Wien, A., 2019. Preference for local food as a matter of helping behavior: insights from Norway. Journal of Rural Studies 67: 79-88. https://doi.org/10.1016/j.jrurstud.2019.02.020

Smith, M.D. and Wesselbaum, D., 2020. COVID-19, food insecurity, and migration. Journal Nutrition 150(11): 2855-2858. https:// doi.org/10.1093/jn/nxaa270

Steinhart, Y., David, M. and Kamins, M.A., 2013. The process by which product availability triggers purchase. Market Letter 24: 217-228. https://doi.org/10.1007/s11002-013-9227-4

Todorovic, V., Maslaric, M., Bojic, S., Jokic, M., Mircetic, D. and Nokolicic, S., 2018. Solutions for more sustainable distribution in the short food supply chains. Sustainability 10: 3481 . https:// doi.org/10.3390/su10103481

Toukabri, M. and Ghali-Zinoubi, Z., 2020. Proximity and confidence in purchasing local food. International Journal of Ecology Development 35(4): 63-77.

Verma, P., 2020. The effect of presentation, product availability and ease upon transaction reliability for online food delivery aggregator applications - moderated mediated model. Journal of Foodservice Business Research 23(4): 285-304. https://doi.org/ 10.1080/15378020.2020.1761586

Xie, X., Huang, L., Li, J.J. and Zhu, H., 2020. Generational differences in perceptions of food health/risk and attitudes toward organic food and game meat: the case of the COVID-19 crisis in China. International Journal of Environmental Research \& Public Health 17: 3148. https://doi.org/10.3390/ijerph17093148

Yadav, R., 2016. Altruistic or egoistic: which value promotes organic food consumption among young consumers? A study in the context of a developing nation. Journal of Retailing and Consumer Services 33: 92-97. https://doi.org/10.1016/j. jretconser.2016.08.008

Yuen, K.F., Wang, X., Ma, F. and Li, K.X., 2020. The psychological causes of panic buying following a health crisis. International Journal of Environmental Research \& Public Health 17: 3513. https://doi.org/10.3390/ijerph17103513 